\title{
Flocculants Optimization In Harvesting Freshwater Microalgae Haematococcus pluvialis
}

\author{
Dina Soes Putri ${ }^{1 *}$, Desy Ambar Sari ${ }^{1}$, Lulu Diani Zuhdia ${ }^{2}$ \\ ${ }^{1}$ Universitas Muhammadiyah Mataram \\ ${ }^{2}$ Universitas Mataram \\ *e-mail: dina.soes.putri@mail.com
}

Received 21 January 2020

Accepted 24 April 2020

\begin{abstract}
Microalgae-based researches are one of the interesting topics to date due to its wide applications for commercial industries. One of the vital issues that remain in the production of large-scale microalgae is the harvesting process of microalgae culture. There are several techniques that can be used in harvesting microalgae and each algae will be showing a different result. In this research, the microalgae Haematococcus pluvialis were harvested using flocculation-filtration method. Alum in different dosages, range from 0.25-2 g/L, was used as flocculants and the mixing duration was investigated to seek out the best harvesting efficiency. Based on the research, it can be concluded that the optimum flocculation process was alum addition of $1 \mathrm{~g} / \mathrm{L}$ culture that continuously stirring for 5 minutes long. In which the flocculation efficiency reaches $94.5 \%$.
\end{abstract}

Keywords:Haematococcus pluvialis, harvesting microalgae technique, flocculants, alum 


\section{Pendahuluan}

Microalgae-based researches are increasing over a decade due to its potential application for commercial uses. As its biomass feedstock can be applied for bioenergy, animal/aquaculture feed, food additives/supplement, nutraceuticals, pharmaceuticals, etc (Ibrahim et al, 2019). The advantages of microalgae as resources for commercial industries are renewable, sustainable and economical (Muhammad et al, 2018). Unfortunately, efficient biomass recovery or harvesting of diverse microalgae species represents a critical bottleneck for large scale microalgae biorefinery process (Ibrahim et al, 2019). Thus, the optimum technique in harvesting each microalga is still under study.

The harvesting techniques for microalgae culture are quietly varied. The common techniques used are: centrifugation, gravity sedimentation, screening, filtration, flotation, flocculation, or a combination of various techniques (Ibrahim et al, 2019; Gulab et al, 2018; Irena et al, 2018). Whereas the flocculation-based process is one of the most preferable technique due to its simplicity, efficiency, scalability, and low cost (Ibrahim et al, 2019; Irena et al, 2018).

Flocculation is the aggregation of unstable and small particles through surface charge neutralization, electrostatic patching and/or bridging after addition of flocculants. Flocs formation allows for separation/recovery by simple gravityinduced settling or any other conventional separation method (Ibrahim et al, 2019). Flocculation process influenced by: cell surface properties, cell concentration, $\mathrm{pH}$ of the environment, ionic strength, type and dosage of flocculants, and mixing process (Irena et al, 2018). There is several flocculants option that can be chosen based on preferences. Two of the common inorganic chemical flocculants used are aluminum and iron salts (Ibrahim et al, 2019).

In this research, the microalgae Haematococcus pluvialis were harvested using flocculation-filtration technique. In which, the flocculant used was aluminum sulfate (commercially known as alum). Anhydrous aluminum sulfate is an odorless white hygroscopic lustrous crystalline solid or powder with molecular weight of $342.2 \mathrm{~g} / \mathrm{mol}$. It has sweet and mildly astringent taste. The boiling point is on $214{ }^{\circ} \mathrm{F}$ and melting point on $3.9^{\circ} \mathrm{F}$. Aluminum sulfate is also obtained as an 18-hydrate $\left.\underline{\mathrm{Al}}_{2} \underline{\mathrm{SO}}_{4}\right)_{3} \cdot 18 \mathrm{H}_{2} \mathrm{O}$. Both forms are soluble in water, noncombustible, and nontoxic. It is used in paper making, in firefighting foams, in sewage treatment and water purification, in vaccine making and other medicinal products, and also can be use as food additive and deodorant (NCBI, 2020). Alum was selected as the flocculants because it is widely available, inexpensive, but results in relatively high harvesting efficiency for some microalgae reported (Ibrahim et al, 2019; Tawan \& Yusuf, 2016). The aim of this research was to find out the best alum dosage and the optimum stirring duration to get the highest harvesting efficiency of microalgae Haematococcus pluvialis culture.

\section{Material and Methods}

\section{Material}

The equipments used in this research were: autoclave, 1L flask, L shape pipe, rubber lid, cotton, aluminium foil, gauze, rubber band, rubber tube, aerator, lamp, luxmeter, thermometer, micropipettes, microtips, bunsen, microscope, haemocytometer, counter, analytical balance,magnetic stirrer, oven, and filterpaper. The chemical used in this research were: Walne medium, aquadest, ethanol $70 \%$, and alum. The microalgae Haematococcus pluvialis were purchased from Ugoplanktonshop, a commercial shop specialize in microalgae culture in East Java-Indonesia. 


\section{Materials Preparation}

All thermo-stabile equipments and Walne medium were sterilized using autoclave for 15 minutes under $121^{\circ} \mathrm{C}$ and 1 psi pressure. Meanwhile, other materials and culture environment were sterililized using ethanol 70\% (Andersen, 2005).

\section{Microalgae Activation and Cultivation}

Activation process was done for 3 days before cultivation to adapt the microalgae starter on a new environment.Microalgae were cultured in sterile environment using Batch technique. Culture total volume was $900 \mathrm{ml}$, algal inoculum was $90 \mathrm{ml}(10 \%$ of total culture volume), nutrient solution added was $900 \mu \mathrm{l}(0,1 \% \mathrm{v} / \mathrm{v})$, and vitamin solution added was $90 \mu \mathrm{l}(0,01 \% \mathrm{v} / \mathrm{v})$ (Andersen, 2005). The culture conditions were: 24 hours of light photo period, light intensity of 2000 lux, room temperature of $28{ }^{\circ} \mathrm{C}$, and aeration for 24 hours (Dina \& Siti, 2019).The cultivation was last for 14 days, when the algae cells begin to enter the death phase (Ahmad et al, 2008).

\section{Microalgae Harvesting}

The microalgae harvesting process was carried out by flocculation method combined with sedimentation(Irena et al, 2018). Alum was used as the flocculants with varying concentrations range from $0.25-3 \mathrm{~g} / \mathrm{L}$ culture. The mixing duration also varied from 3-15 minutes to find out the optimum mixing duration. The flocs then left settle in the bottom of the beaker before being separated with the filtrate using filtration paper. Wet biomass was then being dried using oven at $70{ }^{\circ} \mathrm{C}$ temperature.

\section{Results and Discussion}

Haematococcus pluvialis is a freshwater microalga with a dominantly green cell color when grown in normal or optimum culture conditions. Meanwhile, in extreme or nutrient-depleted conditions the cells will turn into reddish (containing high astaxanthin) (Md. Mahfuzur et al,
2016). In this study, Haematococcus pluvialis were grown in optimum culture conditions (Putri et al, 2019) so that the culture color was greenish. As the culture medium getting older, the green color will be thicker (see Figure 1). Microalgae were cultured for up to 14 days as it begins to enter the death phase (Ahmad et al, 2008).

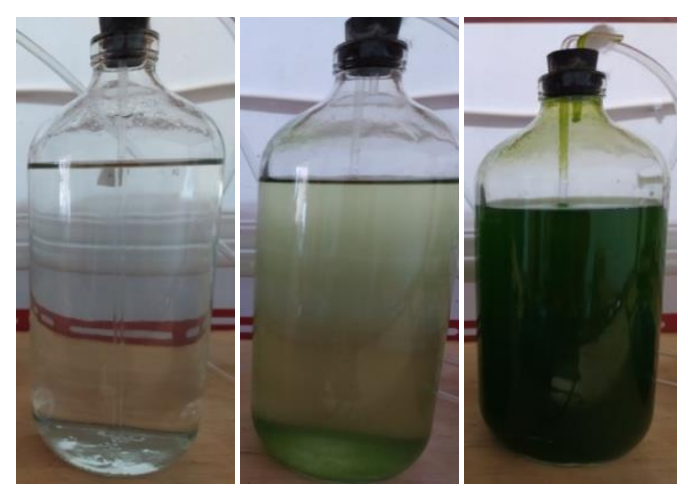

Figure 1. Microalgae culture; from left to right $(\mathrm{H}+0, \mathrm{H}+3, \mathrm{H}+7)$

Microalgae can be harvested with several techniques according to the need (Ibrahim, et al, 2019). In this study, Haematococcus pluvialis was harvested using the flocculation method combined with filtration to obtain the optimal results. The level of harvesting efficiency is determined by several factors (Irena, et al, 2018), including the flocculants concentration and the mixing/stirring duration. One of the common chemical flocculants used for microalgae harvesting is alum. The advantages of alum as the flocculant are affordable, easy to obtain, but the level of flocculation efficiency is quite good so far.

First of all, to find out the best flocculation treatment, several variations of alum concentration were added into microalgae culture. The concentration used starts from $0.25 \mathrm{~g} / \mathrm{L}$ or equivalent to $250 \mathrm{ppm}$ to a concentration of $2 \mathrm{~g} / \mathrm{L}$ or $2000 \mathrm{ppm}$. The results of these experiments can be seen in Figure 2. In plain view, it can be seen that the best variation of alum concentration that can aggregate the most microalgae biomass is the concentration variation between 0.5 or 
$1 \mathrm{~g} / \mathrm{L}$. To ensure the best concentration, flocculation efficiency is calculated by reducing the number/density of the initial cell by the density of the final cell, then divided by the initial cell density and then multiplied by $100 \%$. The results of the calculation of flocculation efficiency based on variations in concentration can be seen in Table 1. Based on data from Table 1 it can be concluded that the more concentrations of alum were added, the more acidic the filtrate was. In which, $\mathrm{pH}$ also contributes to the efficiency of the flocculation process (Irena, et al, 2018). In general, the optimum $\mathrm{pH}$ for flocculation in various types of algae is around 3.5-4 for acidic $\mathrm{pH}$ and in the range of 9.5-12.5 for basic pH (Ibrahim et al, 2019; Gopal et al, 2018). As for Haematococcus pluvialis, the optimum $\mathrm{pH}$ of flocculation is at $\mathrm{pH} 3.76$ with alum concentration of 1 $\mathrm{g} / \mathrm{L}$ of culture will provide flocculation efficiency around $94.5 \%$ (see Table 1). Based on reference, the microalgae flocculation process generally suggested as seen in Figure 3 (Ibrahim et al, 2019).

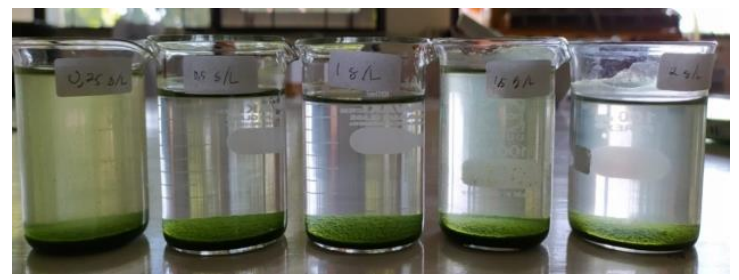

Figure 2. Comparison of Flocculation Results with Concentration/Dosage Variation

Table 1. The Effects of Alum Dosage in Flocculation Efficiency

\begin{tabular}{|c|c|c|c|}
\hline $\begin{array}{c}\text { [alum] } \\
(\mathbf{g} / \mathrm{L})\end{array}$ & $\mathbf{p H}$ & $\begin{array}{c}\text { Cell Density } \\
\left(\times 10^{4}\right. \\
\text { cells/ml })\end{array}$ & $\begin{array}{c}\text { Efficiency } \\
\mathbf{( \% )}\end{array}$ \\
\hline 0 & 6.97 & 109 & - \\
\hline 0.25 & 5.89 & 58 & 46.79 \\
\hline 0.5 & 3.97 & 20 & 81.65 \\
\hline
\end{tabular}

\begin{tabular}{|c|c|c|c|}
\hline 1 & 3.76 & 6 & 94.50 \\
\hline 1.5 & 3.69 & 9 & 91.74 \\
\hline 2 & 3.65 & 49 & 55.05 \\
\hline
\end{tabular}

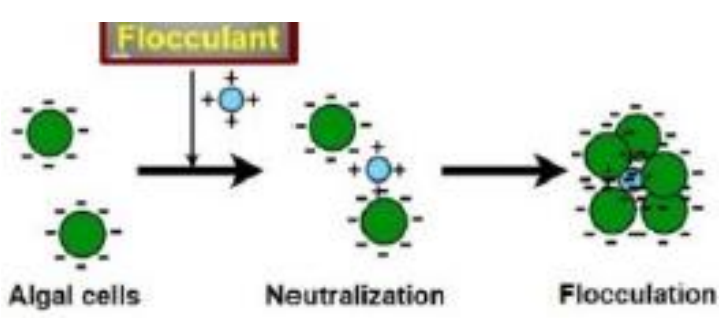

Figure 3. Flocculation Process in Microalgae

Referred to Figure 3, the flocculation process of microalgae Haematococcus pluvialis can be simply explained as below:

1. Microalge cells is a colloidal with negative charge on its surface

2. Meanwhile the flocculants, alum, is a positively charge ion in the water

3. When alum is adding to the algal culture, the positive charge released from alum particle $\left(\mathrm{Al}^{3+}\right)$ will attract the negatively charge on microalgae surface

4. The microalgal cells that once repels each other due to the electrostatic effect become an aggregate (flocs) and close to each other

5. The formation of aggregates (flocs) will make the microalgae cells become dense and settling down by itself due to the gravity effect

Once the algal cells settling down (forming sediment) it can be easily separate from the water.

Secondly, several variations of stirring duration have been tested to $1 \mathrm{~g} / \mathrm{L}$ culture alum concentration to find out the best stirring duration. The results of the experiment can be seen in Figure 4. In plain view, the best stirring duration is shown by the sample with the least microalgae biomass visible floating in the 
filtrate, is at the duration of stirring for 5 minutes. To further ensure the results of this analysis, the remaining cell density in the filtrate have been calculated. The results of cell density calculations can be seen in Table 2. Based on data from Table 2 , it is increasingly clear that the best stirring duration is for 5 minutes.

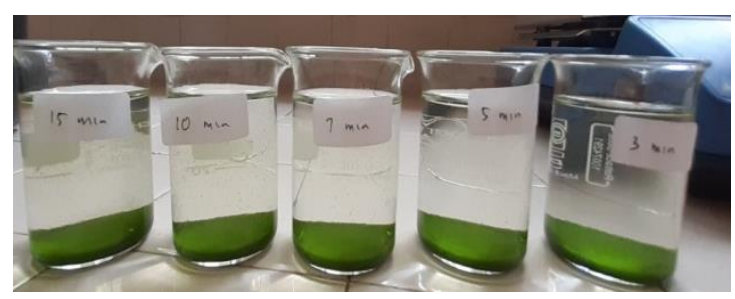

Figure 4. Comparison of Flocculation Results with Variation in Mixing/Stirring Duration

Table 2. The Effects of Stirring Duration in Flocculation Efficiency

\begin{tabular}{|c|c|}
\hline $\begin{array}{c}\text { Stirring } \\
\text { Duration } \\
(\text { minutes })\end{array}$ & $\begin{array}{c}\text { Cell Density } \\
\text { Remain } \\
\left(\times \mathbf{1 0}^{\mathbf{4}} \text { cells/ml }\right)\end{array}$ \\
\hline 3 & 9 \\
\hline 5 & 8 \\
\hline 7 & 11 \\
\hline 10 & 10 \\
\hline 15 & 9 \\
\hline 3 & \\
\hline
\end{tabular}

\section{Conclusion}

The best conditions for optimum flocculation of microalgae Haematococcus pluvialis which reach $94.5 \%$ flocculation efficiency were $1 \mathrm{~g}$ alum added per $1 \mathrm{~L}$ culture with a stirring duration of 5 minutes long.

\section{References}

Ahmad M, Fahruddin, Ida KW, Haryanti. 2008, Kultur Mikroalga Haematococcus pluvalis untuk Menghasilkan Astaxantin, J.Ris. Akuakultur, 3 (3); 351-361

Andersen R. 2005, Algal Culturing Techniques, Elsevier Academic Press, United Kingdom; 21-82

Dina SP, Siti A. 2019, The Growth Comparison of Haematococcus Pluvialis in Two Different Medium, Biota: Biologi dan Pendidikan Biologi, 12 (2); 90-97

Dina SP, Sri PA, Siti A. 2019, The Growth of Microalgae Chlorococcum sp.Isolated from Ampenan Estuary of Lombok Island in Walne's Medium, AIP Conference Proceedings 2199, 050003 (2019)

Gopal KM, Sayantan C, Shoaib H, Pranshanth R, Selvan A, Sibi G. 2018, Microalgae Harvesting via Flocculation: Impact of $\mathrm{pH}$, Algae Species and Biomass Concentration, Methods Microbiol Mol Biol, 2(1), 1-5

Gulab S, S. K. Patidar. 2018, Microalgae Harvesting Technique, Journal of Environmental Management, 217 (July); 499-508

Ibrahim AM, Vu KHB, Mikyoung J, Jung YS, Young-Eun K, Young-Chul L, You-Kwan O. 2019, Flocculation Harvesting Technique for Microalgae: A Review, Applied Sciences, 3069 (9); 1-27

Irena B, Gita P, Tomas P, Zuzana J, Tomas B. 2018, Harvesting of Microalgae by Flocculation, Fermentation, 93(4); 1-12

Md. Mahfuzur RS, Yuanmei L, Jay JC, Maurycy D. 2016, Astaxanthin Producing Green Microalgae Haematococcus pluvialis: From Single Cell to High Value Commercial Product, Frontier in Plant Science, 7, 531

Muhammad IK, Jin HS, Jong DK. 2018, The Promising Future of 
Microalgae: Current Status,

Challenges, and Optimization of a Sustainable and Renewable Industry for Biofuels, Feed, and Other Products, Microbial Cell Factories, 17 (36); 1-21

National Center for Biotechnology Information. 2020, PubChem Compound Summary for CID 24850, Aluminum sulfate. https://pubchem.ncbi.nlm.ni h.gov/compound/Aluminum-sulfate. Retrieved August 22, 2020.

Tawan C \& Yusuf C. 2016, Harvesting Microalgae by FlocculationSedimentation, Algal Research, 13; 271-283 